This item was submitted to Loughborough's Research Repository by the author.

Items in Figshare are protected by copyright, with all rights reserved, unless otherwise indicated.

\title{
Development and characterisation of lithographically printed voltaic cells
}

PLEASE CITE THE PUBLISHED VERSION

http://dx.doi.org/10.1109/ESTC.2006.280177

PUBLISHER

(c) IEEE

VERSION

VoR (Version of Record)

LICENCE

CC BY-NC-ND 4.0

REPOSITORY RECORD

Southee, Darren J., Gareth I. Hay, Peter S.A. Evans, and David J. Harrison. 2019. "Development and Characterisation of Lithographically Printed Voltaic Cells". figshare. https://hdl.handle.net/2134/8479. 
This item was submitted to Loughborough's Institutional Repository (https://dspace.lboro.ac.uk/) by the author and is made available under the following Creative Commons Licence conditions.

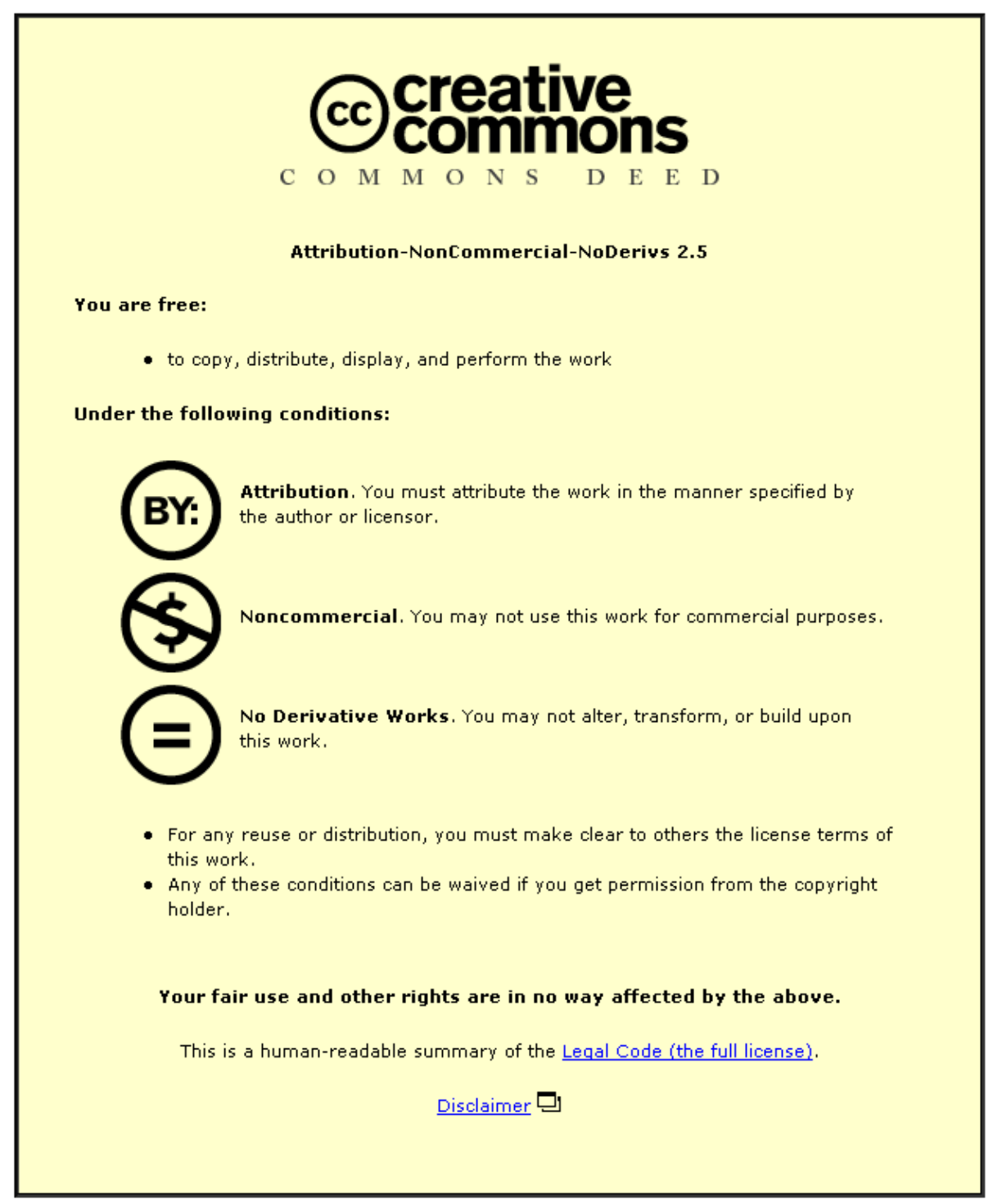

For the full text of this licence, please go to: http://creativecommons.org/licenses/by-nc-nd/2.5/ 


\title{
Development and Characterisation of Lithographically Printed Voltaic Cells
}

\author{
Darren Southee*, Gareth I. Hay, Peter S. A. Evans and David J. Harrison \\ Cleaner Electronics Research Group \\ School of Engineering and Design \\ Brunel University \\ Uxbridge, Middlesex, UB8 3PH, U.K. \\ * Darren.Southee@brunel.ac.uk, +44 (0) 1895274000
}

\section{Abstract}

This paper reports progress in the fabrication of voltaic cells and batteries via offset lithographic printing. Successful design and manufacture of lithographically printed voltaic cells would facilitate the integration of printed passive components, interconnects and display elements for disposable electronics in low-volume, low weight circuits and systems. The Conductive Lithographic Film (CLF) printing process was developed by Brunel University to fabricate circuit interconnect and various passive components at high speed and low cost. A feasibility study, investigating printed cells based on Zinc-Carbon electrochemistry, is described. This has resulted in the production of a printed battery able to power a microcontroller-driven LED display system for more than three hours. Further work seeks to improve cell capacity, address manufacturing process issues, and characterise the structures in more detail.

\section{Introduction}

Conventional "Printed" circuit boards comprise a copper foil bonded to a substrate medium, the circuit image being formed by photo-resist and subtractive etching processes. There are numerous environmental problems associated with the photoresist and etching processes used in conventional "printed" wiring board manufacture. These include:

- Spent etching solutions that are environmental pollutants and incur extra costs in disposal;

- Complex multiple processes are required;

- Toxic materials and waste-products;

- Conventional wiring boards contain lead $(\mathrm{Pb})$ and various fire retardants and fungicides. End of life disposal is therefore environmentally problematic.

Screen-printed conductive films were first widely used for electrical interconnect in the 1940's. The films formed the basis of a thick film technology for producing electronic circuit modules. Thick film techniques developed over the following 60 years, to provide a mature technology with many applications in specialised electronic circuits [1].

The Conductive Lithographic Film (CLF) process was originally developed as an alternative for etched resin-laminate circuit boards. The technique utilises standard offset lithographic printing technology used in the mass production of books and magazines. The CLF process possesses a number of key advantages over more traditional forms of electronic circuit board fabrication:

- High production speed $(6,000-10,000$ impressions/hour)

- Good resolution of image (80 - 100 micron track with 60 micron gap achievable)

- Low cost (low ink volume determining that substrate material proves the largest expense)

- Ability to produce flexible electronic circuits and systems

- Reduced environmental impact (less energy, reduction in material use, easier disposal, toxic heavy metals (e.g. lead) eliminated)

Electrically conductive ink films can be printed on a wide range of flexible substrates including paper and polymer films. A range of passive components and sensor structures have been manufactured by the CLF process by designing structures that exploit the electrical properties of the printed ink films.

In the past few years trends towards greater integration in electronics, combined with reductions in power requirements, and demand for mobility, have led to increasing interest in using additive printing technologies for the production of electronics. The printing of a "disposable" mobile phone, using polymer thick film techniques, received much publicity [2]. Another development is the printing of batteries, using silk-screen technologies to produce zinc anode and manganese dioxide cathode layers fabricated from ink-like 
materials [3]. Developments in thin-film battery technology have been reported by 'Power Paper' an Israeli company who have Patented processes for screen-printing various types of thick-film voltaic cell [4] [5]. Previous research conducted by our group has however established that screen-printed electronic components are both slower to manufacture and significantly more expensive than similar components fabricated by offset lithography. A key feature of the Power Paper screen-printed battery process is a deliquescent electrolyte that attracts sufficient water from the atmosphere to compensate for evaporation losses. Voltaic cells fabricated by the Power Paper process cannot therefore be sealed against leakage or external contamination.

Developments of lithographically printable inks from which anode and cathode electrode structures can be fabricated are presented. The electrode inks which have been developed consist of fine particulates suspended in an alkyd resin containing dilitants to modify the rheological properties, and can be compared to similar inks formed for the manufacture of polymer thick film electronics.

The work has used Leclanché battery chemistry as the base from which lithographically printed voltaic cell electrodes could be formed. The zinc manganese (IV) dioxide Leclanché cell is one of the oldest forms of battery chemistry available. Many variations on the formulation of such cells exist yet much of the details are proprietary to the individual companies involved in their fabrication. However, Leclanché cells are a proven technology and are capable of developing up to $1.7 \mathrm{~V}$ with reasonable currents for general domestic products [6].

The paper describes cell configurations and manufacturing processes while also presenting results demonstrating the performance of cells. These results are discussed and suggestions for improvements in the manufacturing process are proposed.

\section{Discussion 1 Electrode Ink Development}

For a printable CLF ink the formulation must:

- be thixotropic (non-newtonian properties);

- be hydrophobic;

- remain fluid on press but dry quickly when deposited on substrate.

Lithographic printing inks are generally composed from two phases. The first, a colour pigment, takes the form of fine particulates and the second, an ink vehicle, acts as a carrier for the pigmentation through the printing press and provides a bonding mechanism for the pigmentation to the substrate material. Lithographically printable electronic inks developed by Brunel University are similar in composition to commercially available colour inks, such that, formulations are composed from an active 'electronic' material in particulate form (approximately $1-3 \mu \mathrm{m}$ in size) dispersed in an organic resin vehicle.

The ink fabrication process follows closely that of standard lithographic inks and includes;

- Polymeric ink vehicle mixed

- Conductive particulate introduced

- Three roll milling

- Fineness of grind dispersion tested

- Assessment of rheological properties

The polymer based vehicle portion of the ink consists of three components; a polymeric resin, which constitutes the largest portion of the vehicle, a non - volatile dilitant solvent to adjust the viscosity and an anti oxidant agent to retard drying of the ink during printing.

Each component of the ink is combined and agitated until a smooth uniform mixture is formed. To improve distribution of particulates and break down agglomerates the mixture is sheared on a three-roll mill. Without the process of milling it is likely agglomerates of active material will exist, thus reducing the likelihood of the ink attaining the correct rheological properties while also introducing uncertainties to the electrical characteristics of the cured ink film. Breaking down of the agglomerates causes an increase in particulate surface area which, in turn, leads to a larger spread of vehicle over the surface of the active material, causing an increase in viscosity.

To obtain the degree of particulate dispersion and ensure no agglomerates of particulates are present, ink formulations are subjected to Fineness Of Grind testing (FOG test) using a grindometer. A grindometer is a precision fabricated block of stainless steel with two graduated troughs milled into the top surface. The troughs, running along the length of the block, have a start depth of $25 \mathrm{~mm}$ which graduate to $0 \mathrm{~mm}$ as they reach the opposite end of the block. FOG testing is conducted by depositing two beads of ink in either trough at the deepest end and drawing them down the grindometer using a flat edge or blade. The presence of 
agglomerates is apparent should "streaking" be observed in the drawn samples. The location of the streaks along the grindometer gives an indication of agglomerate size.

Ink rheological characteristics are obtained using a cone and plate type viscometer, model Haake VT550. It is important that lithographic printing inks attain the property of thixotropy (shear thinning).

Ink specimens are subjected to shear rates from $0 \mathrm{~s}^{-1}-400 \mathrm{~s}^{-1}$. During testing, measurements of shear stress are recorded and used to calculate the viscosity by the rule:

$$
\eta=\frac{\tau}{\gamma}
$$

where $\eta$ denotes viscosity (Pascalsecond, Pas), $\tau$ denotes shear stress $(\mathrm{Pa})$ and $\gamma$ denotes shear rate $\left(\mathrm{sec}^{-1}\right)$. Ink running through the ink train of a lithographic printing press is likely to be subjected to shear rates in the region of $10,000 \mathrm{~s}^{-1}$, however, in test conditions these shear rates are difficult to reproduce. It is widely accepted that if an ink achieves a viscosity in the region of $7-12$ Pas at $400 \mathrm{~s}^{-1}$, while exhibiting thixotropic behaviour, it is likely to perform well at increased shear rates.

Through a process of ink development, anode and cathode inks based on zinc and graphite particulates respectively were fabricated. The ink formulations utilise active materials with mean particulate distributions of approximately $3 \mu \mathrm{m}$. Composition of each formulation is detailed in Table 1.

\section{Discussion 2 First iteration structure design}

Initial voltaic cells were fabricated by depositing suitable electrode structures using anode and cathode ink formulations. These structures utilising zinc - carbon chemistry were developed to prove that lithographically deposited electrode structures exhibit an electrochemical potential.

Electrode structures were orientated as depicted in Figure 1, such that cells comprised; substrate, cathode layer, electrolyte saturated membrane separator, anode layer, substrate.

The electrolyte mixture was formed by dispersing a small quantity of polyethylene oxide in water followed by the introduction of ammonium chloride. A small quantity of manganese dioxide, in fine particulate form, was introduced to the formulation to act as a depolarising element.
Table 1. Anode and Cathode ink formulation

\begin{tabular}{rcc}
\hline \hline Component & Zinc ink & Graphite ink \\
\hline Mean particulate size: & $3 \mu \mathrm{m}$ & $3 \mu \mathrm{m}$ \\
Particulate (w/w): & $75 \%$ & $33 \%$ \\
XV1578 resin (w/w): & $90 \%$ & $77 \%$ \\
M71A solvent (w/w): & $9 \%$ & $22 \%$ \\
Eugenol anti-oxidant (w/w): & $1 \%$ & $1 \%$
\end{tabular}

Both inks displayed shear thinning and viscosity values in the region of $7-9$ Pas at a shear rate of $400 \mathrm{sec}^{-1}$

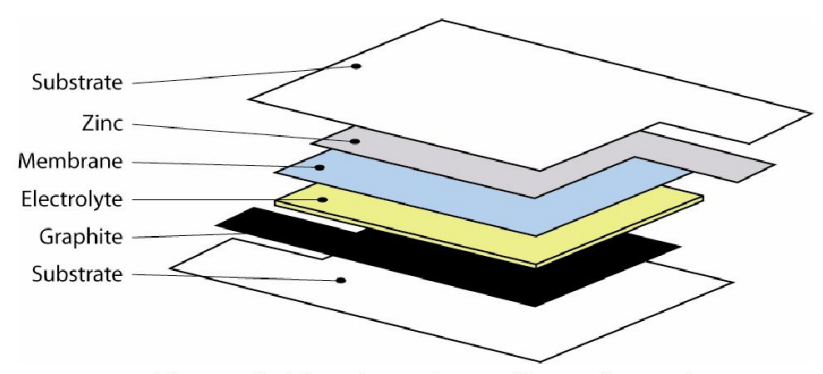

Figure 1. First iteration cell configuration

The principal operation of the membrane separator is to contain the electrolyte preventing migration of this phase through the cell. Cells were sealed using adhesive treated polymer film.

Discharge testing of these initial structures proved that a voltage of $1.5 \mathrm{~V}$ was achievable, however, the current capability of such devises was poor. A peak short circuit current in the region of 2nA was recorded and has been attributed to the high sheet resistance of the graphite and zinc electrode structures (approximately $1.5 \mathrm{k} \Omega / \square$ and $2 \mathrm{M} \Omega / \square$ respectively).

\section{Discussion 2 Second iteration structure design}

The configuration of second generation cells, Figure 2, followed closely that of initial cells, with key differences to electrode structures and the addition of a manganese (IV) dioxide paste. Graphite cathode and zinc anode structures were deposited on top of lithographically printed current collectors formed using a silver loaded conductive ink. Introduction of the current collectors reduces anode and cathode sheet resistivity to approximately $10 \Omega / \square$, resulting in reduced cell internal resistance. 


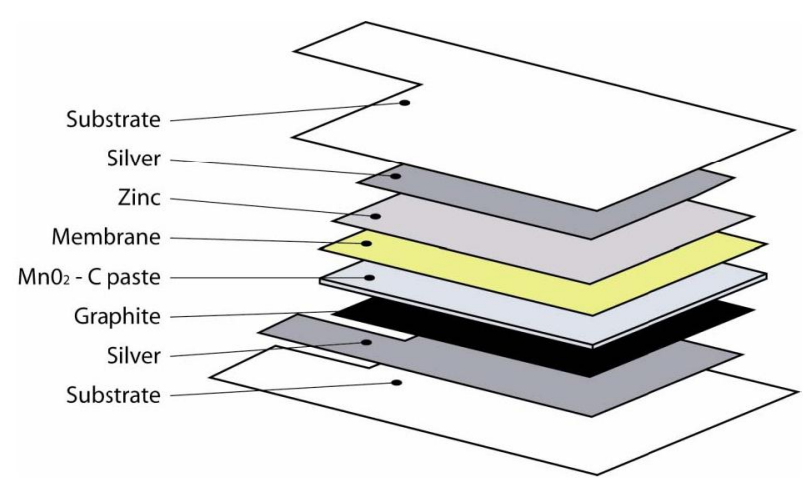

Figure 2. Second iteration cell configuration

Ink films deposited by offset lithography have a thickness of approximately $3-5 \mu \mathrm{m}$, which is in stark contrast to films deposited by screen printing processes (approximately $50 \mu \mathrm{m}$ ) and the thickness of foil material laminated to conventional resin laminate circuit boards (approximately $30-75 \mu \mathrm{m}$ ).

Capacity of a voltaic cell is proportional to the volume of anode and cathode material available for the electrochemical reaction. During discharge of a Leclanché cell, reduction of $\mathrm{MnO}_{2}$ is the cathodic reaction and oxidation of zinc is the corresponding anodic reaction. As such, increasing the volume of cathode material sustains the electrochemical reaction for longer.

Considering the thickness of lithographically deposited films, cell development has focused on the formulation of a 'stencil' deposited manganese (IV) dioxide paste.

As in conventional Leclanché cell design, $\mathrm{MnO}_{2}$ pastes consist predominantly of manganese (IV) dioxide in particulate form mixed with water. In addition to this, carbon/graphite particulates are introduced to the formulation. The addition of graphite to the cathodic paste is important for two reasons. 1. The bulk resistivity of manganese (IV) dioxide is much higher than that of zinc (approximately $1.44 \mu \Omega \mathrm{m}$ and $50 \quad \mathrm{n} \Omega \mathrm{m}$ respectively), hence carbon/graphite is required to reduce the bulk resistivity of the mixture. 2 . Whilst manganese (IV) dioxide is an important element in the electrochemical reaction, it also behaves as a depolarising element, converting hydrogen dissolved in the electrolyte solution (produced by oxidation of the anode material) into water. High concentration of aqueous hydrogen in the electrolyte causes hydrogen bubbles to form, resulting in increased cell internal resistance, hence deteriorating performance. The carbon / graphite portion of the cathodic paste acts as a transport mechanism promoting the ingress of hydrogen in solution into the manganese (IV) paste, hence increasing the surface area of $\mathrm{MnO}_{2}$ participating in the depolarising reaction.

A cathodic paste constituting a $75: 25$ ratio of $\mathrm{MnO}_{2}$ and $\mathrm{C}$ respectively was developed and is detailed in Table 2. During cell fabrication, a cathodic paste layer of approximately $300 \mu \mathrm{m}$ thickness was 'stencilled' over the graphite electrode structure. A paper membrane separator (approximately $500 \mu \mathrm{m}$ thick) saturated with the ammonium chloride electrolyte solution, detailed in Table 2, was positioned over the paste. Finally, the zinc anode was placed above the membrane completing cell fabrication, as detailed in Figure 2.

Table 2. Electrolyte and $\mathrm{MnO}_{2}$ paste composition

\begin{tabular}{|c|c|c|c|}
\hline \multicolumn{2}{|c|}{$\begin{array}{c}\text { Manganese (IV) dioxide } \\
\text { paste formulation }\end{array}$} & \multicolumn{2}{|c|}{ Electrolyte Composition } \\
\hline $\mathrm{MnO}_{2}$ : & $42.9 \%$ & $\mathrm{NH}_{4} \mathrm{Cl}$ : & $25 \%$ \\
\hline $\mathrm{C}:$ & $14.2 \%$ & Water: & $75 \%$ \\
\hline Water: & $42.9 \%$ & & \\
\hline
\end{tabular}

Second iteration structures were evaluated via constant discharge through a $5 \mathrm{k} \Omega$ load for 105 minutes. A typical discharge curve produced during evaluation is depicted in Figure 3.

Figure 3 suggests that discharge characteristics of lithographically deposited voltaic cells are not dissimilar to that expected from conventional Leclanché cell technology. Cell voltage is noticed to fall off at an increased rate during the first 80 minutes of discharge, after which, the rate of voltage drop decreases.

However, it is apparent that the expected cell potential of $1.5-1.7 \mathrm{~V}$ is not obtained from the second iteration cell design. This is attributed to the resistance of the membrane separator utilised for this configuration.

Analysis has proven that the shelf life of second iteration cells is poor. Under no load, cell potential falls below $80 \%$ of maximum within 3 hours. One hypothesis to explain this characteristic concerns the substrate material employed for electrode fabrication. Teslin is a polyethylene based material designed for the printing industry, and is favoured for its high quality graphic reproduction, due predominantly to the surface composition. During manufacture, the extruded polyethylene is impregnated with silica to create a highly porous sheet. As such, approximately $60 \%$ of the materials volume is air. While aiding ink adhesion, due to absorption of the ink vehicle into the substrate surface, it is believed that the electrolyte phase of 


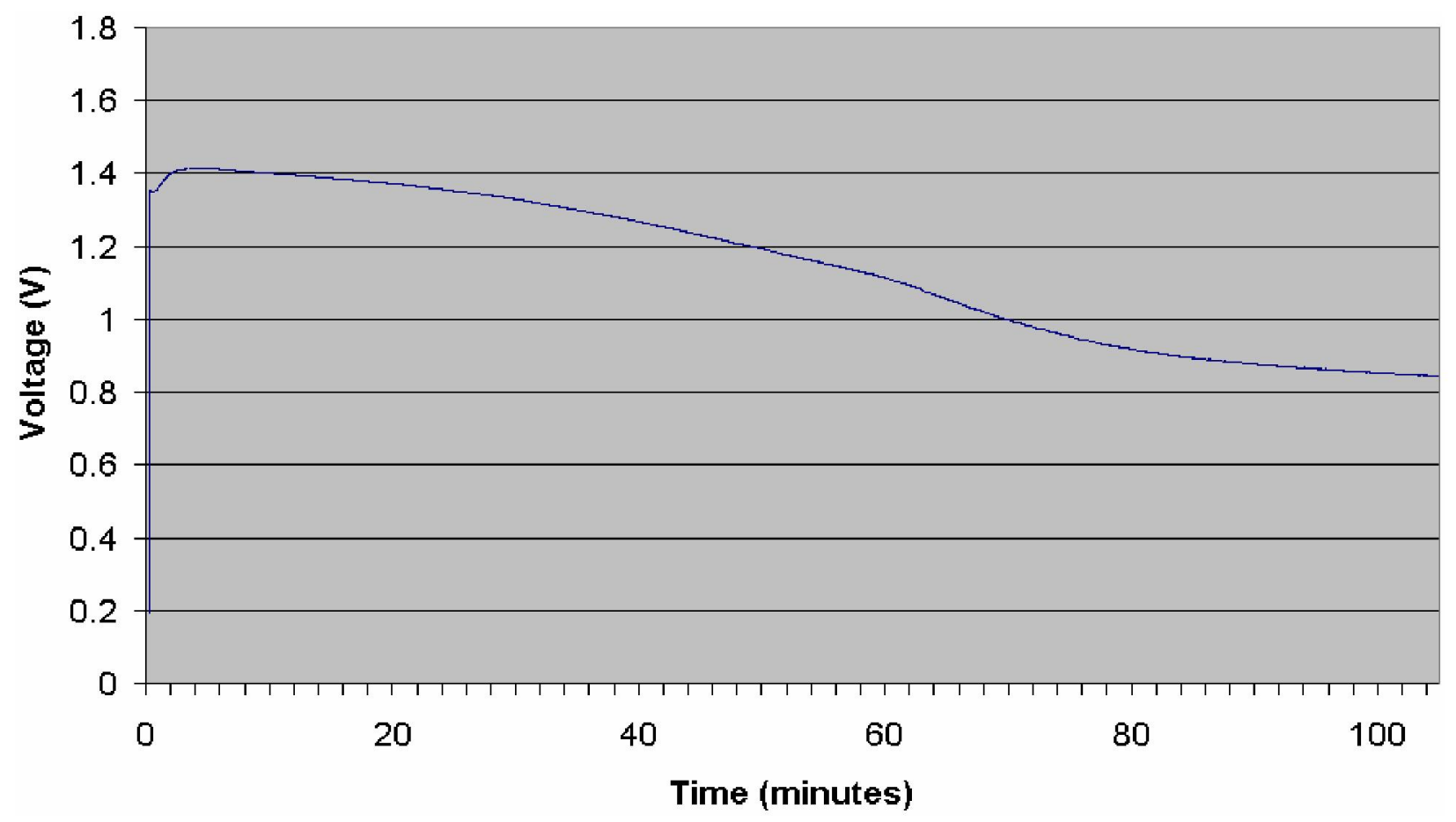

Figure 3. Second iteration cell discharge characteristics

cells permeates the material and is drawn away from the cathodic and anodic materials, hence reducing cell capacity.

\section{Conclusions}

This paper describes a process of using offset lithographic printing to form electrode structures suitable for voltaic cell fabrication. Anode and cathode inks have been developed using active material in a particulate form suspended in a polymeric resin. Inks developed attain hydrophobic and thixotropic properties necessary to facilitate lithographic printing.

First iteration cells proved that suitable electrode materials could be printed and realised the chemical potential of Leclanché chemistry. Second iteration structures utilising silver current collectors achieved superior current capability compared to their predecessors.

Second iteration cell structures have been combined in a battery to power a microcontoller circuit incorporating an LED array for over 3 hours, Figure 4.

\section{Future work}

It has been shown that the Conductive Lithographic Film printing process can be used to form electrode structures suitable for voltaic cell fabrication. It is proposed that the short shelf life of such cells is due to electrolyte absorption of the substrate material. Current work is concerned with the deposition of electrode structures on non porous PET substrate materials. The successful utilisation of such materials should extend cell shelf life by preventing electrolyte migration away from the electrochemically reactive materials.

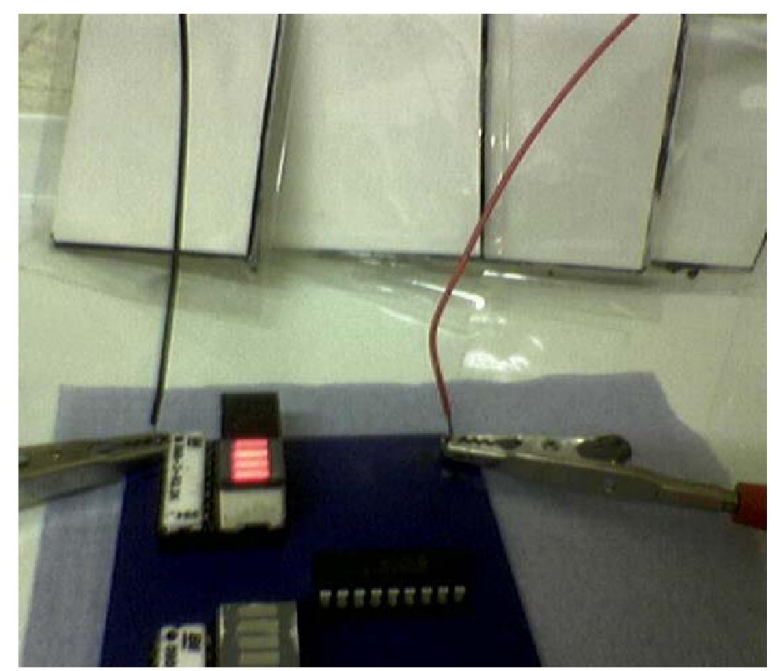

Figure 4. Lithographically printed battery- powered circuit

Ongoing development of cathodic pastes will further increase cell capacity by optimising the ratio of manganese (IV) dioxide to graphite particulates.

While the predominant concern of this work is the development of a 'clean' printed power source, it is widely accepted that the inclusion of zinc chloride 
in the electrolyte phase increases the efficiency of Leclanché chemistry. The inclusion of zinc chloride has to date been discouraged due to the toxic nature of the material.

Development of a lithographically printable manganese (IV) dioxide / graphite ink is underway. Problems associated with high sheet resistivity are currently being investigated. A lithographically printed layer is desirable to replace the cathodic paste. Due to the thin nature of lithographically deposited ink films, it is envisaged that a cathodic ink layer will require over printing a number of times to achieve suitable ink volume. It is therefore necessary to formulate a printable ink which, while attaining a suitable sheet resistivity, will also achieve a low modulus of elasticity. This is necessary to prevent cured ink film cracking during over printing.

\section{Acknowledgments}

The authors would like to thank Narinder Bains (Rohm and Haas Electronic Materials Europe Ltd.), Peter Herdman (Arjo Wiggins Fine Papers Ltd.) and Bill MacDonald (Dupont Teijin Films Ltd.) for their assistance in support of this work. Thanks also to the IeMRC for funding the feasibility study.

\section{References}

1. GILLEO, K. Polymer Thick Film Technology, John Wiley \& Sons Inc., 1996.

2. Altschul, R L. Disposable Wireless Telephone Method, US Patent No. 5845218.

3. http://www.powerpaper.com/3_technology/ batteryspecs.htm, [site visited 06/05/05]

4. Baruch Levanon. Flexible Thin Open Electrochemical Cell And Applications of Same, US Patent No. 575190. December 20, 1995.

5. Power Paper Inc. Flexible Thin Open Electrochemical Cell And Applications of Same, US Patent No. 873868. June 12, 1997.

6. VINCENT, C. A., SCROSATI, B. Modern batteries: An introduction to electrochemical power sources. $2^{\text {nd }}$ edition. Arnold, U.K., 1997. 